\title{
MYSTERY SHOPPERS AND NET PROMOTER SCORE TOOLS FOR CUSTOMER SATISFACTION IMPROVEMENT
}

\author{
Goce Boceski ${ }^{1}$, Gligorče Vrtanoski ${ }^{2}$
}

\author{
${ }^{I}$ MSc Student at the Faculty of Mechanical Engineering, "Ss. Cyril and Methodius" University in Skopje, \\ P.O. Box 464, MK-1001 Skopje, Republic of North Macedonia \\ ${ }^{2}$ Faculty of Mechanical Engineering, "Ss. Cyril and Methodius" University in Skopje, \\ P.O. Box 464, MK-1001 Skopje, Republic of North Macedonia \\ gligorche.vrtanoski@mf.edu.mk
}

\begin{abstract}
A b s t r a c t: In conditions of high levels of globalization and strong competition, customer satisfaction is an essential prerequisite for their loyalty and successful retailing. Defining measurable parameters that affect customer satisfaction is a prerequisite for measuring and tracking them. The AIDA model is the basis of the sales funnel concept that allows defining and measuring the value conversions of one funnel element to another. Through an analysis of two case studies: a local retail chain and an international Toyota retail, both based on the AIDA model, adapted sales funnels and conversion indicators of the sales funnel elements are presented as a measure of the success of the retail chain. Two methodologies for creating customer satisfaction are analyzed: BIG 4 and AWOS, including the tools: Upsale and CrossSale to enhance it. In addition to the thesis on the importance of customer satisfaction and the power of its influence, surveys of local sales staff and views of top world managers are presented. The importance of feedback from customer to company is demonstrated through realistic values from the application of two tools: Mystery Shoppers MS, and Net Promoter Score - NPS. The process of defining an adapted sales conversion funnel is presented which is practically applied through the analysis of two case studies. The cases demonstrate the importance of educating sales staff, as well as the impact of marketing and commercial campaigns on sales success. The conclusion of the research is that customer satisfaction is a prerequisite for successful retailing and a major competitive advantage that should be constantly in the focus of every successful company.
\end{abstract}

Key words: customer satisfaction; sales funnel; AIDA models; conversion rates indicators; competitive advantage; mystery shoppers; net promoter score

\section{АЛАТКИТЕ МИСТЕРИОЗНИ КУПУВАЧИ И „NЕT РRОМОТЕR SCORE“ 3А ПОДОБРУВАњЕ НА ЗАДОВОЛСТВОТО НА КЛИЕНТИТЕ}

А п с т р а к т: Во услови на висок степен на глобализација и силна конкуренција, задоволството на купувачите е основен предуслов за нивна лојалност и за успешна малопродажба. Дефинирањето на мерливи параметри кои влијаат врз задоволството на клиентите е услов за нивното мерење и следливост. Моделот AIDA е основа на концептот продажна инка кој овозможува дефинирање и мерење на конверзиите на вредностите на еден елемент од инката во друг. Низ анализа на практичното работење на два система: локален малопродажен синџир и интернационална организација на малопродажба на Тојота, двата базирани на моделот AIDA, прикажани се приспособени продажни инки и индикатори на конверзии на елементите од продажната инка како мерило за степенот на успех на малопродажниот синџир. Анализирани се две методологии за креирање задоволство кај клиентите и неговото зголемување: BIG 4 и AWOS, вклучувајќи ги алатките Upsale и CrossSale. Во прилог на констатацијата за важноста на задоволството на клиентите и моќта на неговото влијание се презентирани анкети на локален продажен персонал, но и ставови на врвни светски менаџери. Важноста на повратната спрега на информации од клиентите до компанијата е прикажана низ реални вредности преку примена на две алатки: мистериозни купувачи - MS, и Net Promoter Score - NPS. Претставен е процес на дефинирање адаптирана продажна инка на конверзии, практично применет низ анализа на студии на два случаја. Случаите ја покажуваат важноста на едукацијата на продажниот персонал, но и влијанието на маркетиншките и комерцијалните кампањи врз успешноста на продажбата. Заклучокот од истражувањето е дека задоволството на клиентите е предуслов за успешна малопродажба и главна конкурентска предност којашто мора да е постојано во фокусот на секоја успешна компанија.

Клучни зборови: задоволство на клиент; продажна инка; модел AIDA; индикатори на конверзија; конкурентска предност; мистериозни купувачи; net promoter score 


\section{INTRODUCTION}

The paper investigates entities which exploits certain segments of quantitative methods of analysis. In the first segment, the so-called "sales funnel" $[1,6]$ of customer traffic of one representative of the automotive industry is investigated and retail consumer chain is presented for the process of analyzing sales services and customer satisfaction.

Compatible with these analyses are customer satisfaction surveys, which analyse and consider the following methodologies and tools:

- Inchcape's AWOS (Advanced Way of Selling) methodology [7];

- BIG4 methodology (access, welcome, recognition, testing) [10];

- Retail chain NPS (Net Promoter Score) [9, 1];

- Mystery shoppers tool on example of several companies $[8,1]$.

Quantitative methods not only optimize and measure the success of product sales processes but also provide a basis for measuring the success of marketing actions and invested funds.

One of the main goals of marketing campaigns is to bring physical customer traffic to the outlets that would convert it into a successful sale of products and/or services. Customer traffic conversion analysis is a key benchmark for the success of spent budget funds and the basis for their planning for the future.

Customer satisfaction analysis supports the results and provides the opportunity for fine-tuning of sales processes.

Maintaining optimal product stocks and sales points display is far easier when sales planning and seasonality measurement is supported by clear and measurable parameters. Seasonality is confirmed by metric methods that unambiguously reflect consumer habits, sensitivity to marketing actions, and the degree of service provided by sellers. It also gives a clear picture of when, where, how much and what stock of products a company should have.

\section{AIDA MODEL, METHODS AND TOOLS FOR CUSTOMER SATISFACTION}

In the analysis of creating and measuring customer satisfaction and traffic, sales funnel is the main operational tool. There are different definitions of what a sales funnel actually represents, but the most accepted one is that a sales funnel is a process of successive conversions where one phase output represents an input for the next one with each conversion output being a subset of the input. In other words, the sales funnel is an interpretation of the AIDA (Access, Interest, Desire, Action) model, set and defined by entrepreneur Elias St. Elmo Lewis, in 1898, and consisted of four elements [1, 2]:

- Awareness (the customer is aware of the existence of a particular product or service).

- Interest (active interest in a particular product category).

- Desire (aspiration to a particular brand, product or service).

- Action (concrete action to buy a particular product).

The concept of sales funnel according to AIDA model represents basis for the funnel of customer traffic conversion as well as the basis for modern Customer Relationship Management (CRM) modules and programs. It has been documented for the first time, analyzed and published in the book Bond Salesmanship [13].

One of the companies that have been practicing systems and procedures to control and increase customer satisfaction for decades are Toyota Motor Corporation and Inchcape PLC. Toyota's basic settings are represented in a set of principles called the Toyota Way [11], as well as the Toyota Code of Conduct [10]. The need to establish standards and procedures is recognized in Toyota's retail network and Inchcape PLC. The set of procedures and documents was materialized in 2009 through the Advanced Way of Selling - AWOS [7]. The standards in consumer electronics retailing are not the same as above, primarily due to the diversity of the industry, but they're based on equal principles and values. They are presented through the presentation and analysis of a set of sales standard procedures united in the 7 Steps Sales Manual [1]. Improving the customer experience should be further enhanced by the tools of Upsale and Cross-Sale [3, 1]. All of these systems to increase customer satisfaction will not be complete without feedback, that is, how customers experience and evaluate their own experience. Researcher Peter Murley [12] through a series of research from different industries makes clear recommendations on how to improve a customer's shopping experience. It shows models of techniques of conducting telephone and direct calls and how to choose the right performance indicators. 
Completeness of the above mentioned feedback for evaluating the customer experience is provided with the tools: mysterious customer - MS [8, $1]$, and Net Promoter Score - NPS [9, 1].

The first, mysterious customer - MS $[8,1]$, is actually a measure of the degree of implementation of company standards, and the second, Net Promoter Score - NPS, is a survey of what is important to customers and how they feel about the service they receive.

The NPS tool $[9,14,1]$ was developed and registered trademark, officially launched by economist and business strategist Fred Reichheld in 2003 [12]. Research has shown that increased corporate value of NPS results in increased company turnover [1]. Through an analysis of the three-year period of monthly logging of mysterious customer (MS) values and NPS in Toyota's retail network provided by IA (Inchcape Advantage portal) and AWOS [7], the NPS tool has proven to be a top-notch tool for monitoring, tracking and enhancing customer satisfaction. The paper [8] presents a survey in several companies that answers the question of what this tool is, how it should be implemented in a company and the most important, which set of questions should be used and why.

In the context of the provided methodologies and tools that set sales process standards, salesman education, and defined adaptive sales funnel following the AIDA model, conversion indicators need to be defined. They should be measurable and clearly correlated with the sales process. In his work [6], researcher Aaron Hoos, based on an analysis of several companies, including his own, answers how to generate more Leads, turn them into customers and make it faster, easier and with more profits.

Improved customer traffic conversions lead to increased profit and sales success, but they should not be at the cost of a disrupted shopping experience. Client surveys and surveys of carefully targeted focus groups are a good tool in managing the shopping experience. Researcher Sheila Kessler [4] describes a systematic approach to planning, conducting and obtaining the results of her customer opinion research. It describes activities in the area of customer satisfaction surveys, focus groups, and methods of analysis and synthesis.

\section{MYSTERY SHOPPERS AND NET PROMOTER SCORE TOOLS}

One of the most widespread traditional tools in the process of sales analysis and customer satisfaction is Mystery Shoppers (MS) [8, 1]. In exploring opportunities to build a more loyal customer base at a time when traditional sales channels are dramatically changing, consumers' social habits are changing. In such conditions managers are asked the question: what are the methods that need to be used in order for a company to effectively measure customer service.

Technology and digital social communication methods are easying researching target groups and how customers feels about the service provided. At the same time, advances in the general culture of providing customer feedback means that opportunity is being created for new tools to measure customer satisfaction. The most well known and most widely used of its kind is the Net Promoter Score (NPS) tool $[9,1]$.

This new tool, NPS, is complementary to the Mystery Shoppers (MS) tool. One very simple reason for this complementarity is that MS and NPS surveys conducted for customer satisfaction are absolutely two different things that should not be overlooked. Two brief definitions are used to explain and clarify $[8,9]$.

What is a Mystery Shoppers - (MS) tool? It is a measure of the degree of implementation of company standards.

What is a NPS customer satisfaction tool? It is a request for information from customers about what is important to them and how they feel about the service they receive from the company.

Net Promoter Score (NPS) or widely accepted Net Promoter $[9,1]$ is a modern management tool that can be used to measure customer loyalty with the company. This tool is relatively new and can serve as an alternative to traditional customer satisfaction research and company research. It shows the correlation of revenue growth.

Calculating the value of a company, NPS is as simple as the whole system.

The NPS system begins with the results of customer surveys, as indicated in the first request of the NPS tool to the company that implements it. Survey ratings are in a linear scale of 0 to 10 , with scores of 9 or 10 denoting a Promoter, scores of 7 and 8 Passive, and scores of 0 to 6 Detractor. The NPS score is calculated simply, as opposed to the percentage of Promoter (Prom\%) reduced by the percentage of Detractor (Det\%) $[12,1]$ :

$$
\text { NPS }=\text { Prom } \%-\operatorname{Det} \% \text {, }
$$

where:

- Prom\% represents the percentage of Promoter from total customers surveyed, and 
- Det\% represents the percentage of detractors from the total clients surveyed.

Passives are ignored because they neither affect them negatively nor positively.

Consequently, the calculated value of the company NPS rating is a size that can be between $100 \%$ maximum satisfaction and $-100 \%$ maximum satisfaction.

The momentum of different cultures, consumer habits and standards of service in a society are also factors that strongly influence NPS values and their diversity depending on which geographic area the same product is being researched by the same company [1].

\section{ANALYSIS, MEASUREMENT AND CONVERSION OF CUSTOMER TRAFFIC IN THE AUTOMOTIVE INDUSTRY - CASE STUDY -}

There are several corporations in the automotive industry that have been key players for years, including the inevitable name of Toyota Motor Corporation. As a group, it has for years been in the top three by volume of sales, as well as undisputed No. 1 in the world as the best-selling brand in the last twenty years. Toyota's philosophy and approach to business is materialized in the so-called Toyota Way [11], which is a set of principles and procedures that define and guide every action and action a company takes.

The BIG 4 and AWOS methodologies developed by Inchcape PLC and Toyota find great practical application by analyzing the differences in markets with similar mentality and economic power. Through consistency in their application they allow to define the parameters needed to be measurable and traceable, but the long-range measurements and traceability additionally provide builtin seasonality and history within themselves. This highlights the regularities in the relationships between the various parameters that are the subject of measurement.

Having a range of variations of such data from different markets is an opportunity to verify, compare and determine any adjustments. Once these laws and their correlations are known, the second stage is to determine the navigation processes that will result in higher conversion rates, more efficient sales and increased customer satisfaction.

If the applied methodologies of BIG 4 and AWOS have created a basis for strong customer satisfaction creation potential, it is necessary to select the measurable parameters already set in the AIDA model, graphically presented in Figure 1.

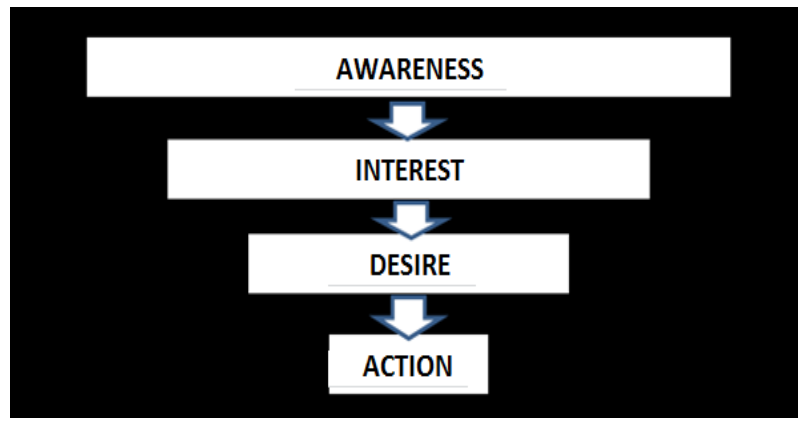

Figure. 1. AIDA model elements [15]

Using the AIDA model, the task of the marketing department is to create awareness among as larger as possible group of potential customers. Part of that group should be interested in the narrow category of products in question, with some of them wishing to do so, and a smaller proportion of them taking specific action, that is, making contact with the seller. Once customers have reached the location of the product and/or service provider, the main task of marketing and advertising and promotions is complete. Now, the responsibility shifts to management and the sales team $[1,3,5]$.

The analysis suggests that it is necessary to modify the sales funnel in an active metric element conversion process. The choice of those elements largely depends on industry, geolocation, cultural and social habits, but in the specific case of the automotive sales process that is the subject of this analysis, it comes down to creating four new elements. These 4 new elements are shown in Figure 2 and represent:

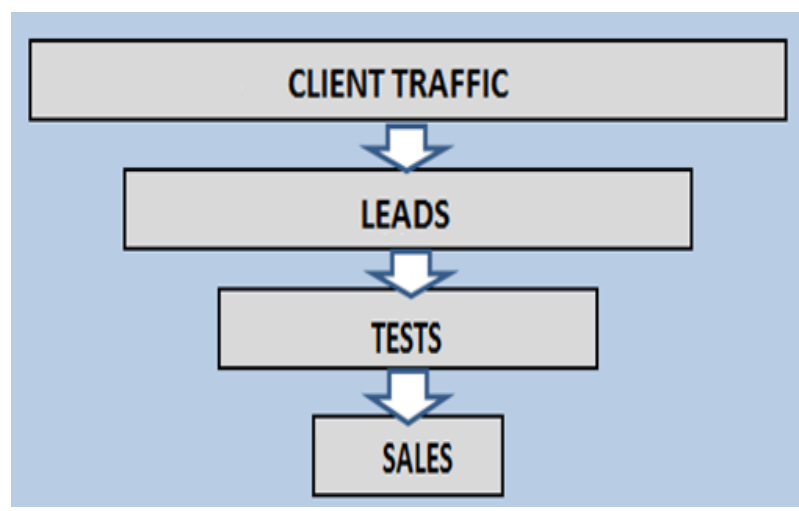

Fig, 2. Sales funnel with active metric element of conversion [1] 
A) Client traffic as an element that can be considered integral or separate from the other three types of traffic: physical, internet and telephone traffic. Separate analysis is more accurate, as there is always a partial overflow of the Internet and telephone traffic, and on the other hand it is often a different category of audience with different consumer habits. Conversion of traffic to numeric values follows the following rules [7]:

- Physical traffic: every customer who enters for the first time at the point of sale in the last 3 months and continuously visits an unlimited number of times during that period is valued as one customer traffic. If the client has not arrived for 3 or more months it is considered that there is no active request and is revalued at the first next visit.

- Internet traffic: every customer who addresses by email, or will stay more than 3 minutes on the website, or interacts with social media with an active and clearly expressed interest, is valued as one customer traffic for a period of three months.

- Telephone traffic: each call with a clearly expressed interest is reevaluated within a period of three months with a value of one for the first call.

B) Leads. The leads element comes from the English word "leads" and indicates any customer traffic customers who may be contacted again. They may have left a phone number, a home address, an office phone, an email address, or any other type of "trace", all of which leads and the seller has the opportunity to contact them on the basis of a quote, price change information, campaign, etc. The number of such clients is actually the value of the leads element.

C) Testing. The portion of leads that went further than leaving some sort of trace and switch on product testing forms, represents the value of the testing element. This is the crucial element, because the buyer faces a kind of simulation of what it would look like if he actually owned the product that at that moment was only a potential purchase. Active salesman interaction, a high level of product knowledge and customer feedback identification are required.

D) Sale. If all elements of the sales funnel and conversion process are executed to a high degree of quality, the sale is a crown itself as a result of previously performed procedures and standards. Sales is the ultimate goal of the entire organization after which the product enters in the third phase of its life cycle (after production and sale), i.e. the stage of exploitation by the end user.
This type of sales funnel provides six types of conversion indicators, the main of which are $[6,7]$ :

1. Traffic to Sales - TrS, denotes the conversion rate of customer traffic into actual sales, and is given by the following equation:

$\operatorname{TrS} \%=100 *$ sales $/$ customer traffic.

2. Traffic to Leads - TrL, denotes the conversion rate of customer traffic into leads, and is given by the following equation:

$\operatorname{TrL} \%=100 *$ leads $/$ customer traffic.

3. Traffic to Tests - TrT, denotes the conversion rate of customer traffic into realized tests, and is given by the following equation:

$\operatorname{TrT} \%=100 *$ tests $/$ customer traffic.

4. Leads to Tests - LT, denotes the conversion rate of leads into realized tests, and is given by the following equation:

$$
\text { LT }=100 * \text { tests } / \text { leads. }
$$

5. Leads to Sales - LS, denotes the conversion rate of leads to actual sales, and is given by the following equation:

$$
\mathrm{LS} \%=100 * \text { sales } / \text { leads. }
$$

6. Tests to Sales - TS, denotes the conversion rate of a number of tests to actual sales, and is given by the following equation:

$$
\mathrm{TS} \%=100 * \text { sales } / \text { tests. }
$$

Although in practice, usually $\mathrm{TrS} \%$ is indicator of the success of a retail organization, absolutely all indicators are of equal importance and should be viewed and analyzed integrally.

$\mathrm{TrS} \%$ is a quantitative indicator of how much percentage sales a certain number of customers have made. For example, if $\mathrm{TrS} \%$ is $20 \%$, it shows that every fifth customer who entered a particular point of sale purchased a particular product.

When transforming a business that does not measure quantitatively sales success and customer satisfaction, to a company that implements it, what first comes as a "surprise" is data consistency. The experience of companies that have implemented such systems for many years shows that in similar or identical conditions the conversion factors are extremely stable. This applies not only at the company level but also at the individual level. This provides a huge opportunity for listing conversion rates that will lead to higher sales. 
In this context, the importance of the third element of the AWOS methodology is emphasized, namely the IA (Inchcape Advantage) portal. It is an international digital database of processed sales conversion funnel data, from each market, from each store, to each sales person individually. If it is previously emphasized that the key and greatest benefit is the ability to specify conversion indicators, the IA (Inchcape Advantage) portal provides an additional opportunity to learn not only by analyzing own seasonality and history, but also by other companies related to their results and tools that they have achieved or missed. In doing so, socio-economic and cultural differences between different markets or parts within a market must be taken into account.

Analyzing the differences in the three neighboring markets with similar mentality and economic power (Romania, Bulgaria and Greece), they differ extremely slightly and move with a $\mathrm{TrS} \%$ value of approximately $15 \%$. These three countries not only have similar values of indicators, but also represent a commercial whole. It is an additional factor for the importance of comparative data monitoring by management.

Table 1 shows the conversions of the main retail outlets of Macedonia and Greece, i.e. comparative conversion indicators for Skopje, Thessaloniki and Athens.

Based on the analysis of the data given in Table 1 it can be seen that there is almost no difference between the Athens, Thessaloniki and Skopje retail outlets, i.e. $\operatorname{TrS} \%=9.4 \%$ in Athens, $\operatorname{TrS} \%=$ $10.6 \%$ in Thessaloniki, $\mathrm{TrS} \%=9.3 \%$ in Skopje. It shows that the thesis that markets with similar cultural habits, purchasing power, tradition, number of cars within a family have similar conversion indicators, applies not only to the whole market level, but also to the individual city level.

In addition to the comparisons of different regions, markets and retail outlets within those markets, a more detailed comparison has been made at seller level. Table 2 shows the conversion indicators measured for 4 different retailers from the same retail outlet in Greece, which receive the same number of customer traffic units per unit time. The case under consideration is for a period of one month.

Table 1

Conversion indicators of retail outlets at Thessalonici, Athens and Skopje [1]

\begin{tabular}{lcccccccc}
\hline \hline & Full & Average & Jan & Feb & Mar & Apr & May & Jun \\
& 2008 & 2008 & 2009 & 2009 & 2009 & 2009 & 2009 & 2009 \\
\hline Inchcape Retail Salonica - Greece & & & & & & & & \\
Phone & 4252 & 354 & 268 & 250 & 217 & 307 & 289 & 214 \\
Leads & 0 & 0 & 0 & 0 & 0 & 0 & 0 & 0 \\
Footfall & 5350 & 446 & 455 & 450 & 388 & 543 & 442 & 376 \\
Leads & 3737 & 311 & 253 & 229 & 201 & 320 & 265 & 234 \\
Total traffic & 9602 & 800 & 723 & 700 & 605 & 850 & 731 & 590 \\
Total leads & 3737 & 311 & 253 & 229 & 201 & 320 & 265 & 234 \\
Test & 1719 & 143 & 73 & 71 & 59 & 271 & 59 & 51 \\
Sales & 1022 & 85 & 64 & 54 & 58 & 138 & 139 & 121 \\
\hline KPI (Gold Standard) & & & & & & & \\
TrL\% - Phone traffic to leads (\%) & 0.0 & 35.0 & 0.0 & 0.0 & 0.0 & 0.0 & 0.0 & 0.0 \\
TrL\% - Footfall traffic to leads (\%) & 69.9 & 65.0 & 55.6 & 50.9 & 51.8 & 58.9 & 60.0 & 62.2 \\
LT (\%) & 46.0 & 50.0 & 28.9 & 31.0 & 29.4 & 84.7 & 22.3 & 21.8 \\
TS (\%) & 59.5 & 55.0 & 87.7 & 76.1 & 96.3 & 50.9 & 235.6 & 237.3 \\
TrS (\%) & 10.6 & 14.2 & 8.9 & 7.7 & 9.6 & 16.2 & 19.0 \\
\hline Inchcape Retail Athens Heraklio - Greece & & & & & & 20.5
\end{tabular}




\begin{tabular}{|c|c|c|c|c|c|c|c|c|}
\hline & $\begin{array}{l}\text { Full } \\
2008 \\
\end{array}$ & $\begin{array}{c}\text { Average } \\
2008 \\
\end{array}$ & $\begin{array}{c}\text { Jan } \\
2009 \\
\end{array}$ & $\begin{array}{c}\text { Feb } \\
2009 \\
\end{array}$ & $\begin{array}{l}\text { Mar } \\
2009 \\
\end{array}$ & $\begin{array}{c}\text { Apr } \\
2009 \\
\end{array}$ & $\begin{array}{l}\text { May } \\
2009 \\
\end{array}$ & $\begin{array}{c}\text { Jun } \\
2009 \\
\end{array}$ \\
\hline Footfall & 3413 & 284 & 395 & 303 & 374 & 706 & 501 & 343 \\
\hline Leads & 2468 & 206 & 309 & 235 & 282 & 449 & 340 & 243 \\
\hline Total traffic & 6391 & 533 & 684 & 511 & 636 & 1141 & 782 & 510 \\
\hline Total Leads & 2468 & 206 & 309 & 235 & 282 & 449 & 340 & 243 \\
\hline Test & 843 & 70 & 123 & 85 & 115 & 138 & 90 & 60 \\
\hline Sales & 600 & 50 & 47 & 30 & 44 & 101 & 80 & 57 \\
\hline \multicolumn{9}{|l|}{ KPI (Gold Standard) } \\
\hline TrL\% - Phone traffic to leads (\%) & 0.0 & 35.0 & 0.0 & 0.0 & 0.0 & 0.0 & 0.0 & 0.0 \\
\hline TrL\% - Footfall traffic to leads (\%) & 72.3 & 65.0 & 78.2 & 77.6 & 75.4 & 63.6 & 67.9 & 70.8 \\
\hline $\mathrm{LT}(\%)$ & 34.2 & 50.0 & 39.8 & 36.2 & 40.8 & 30.7 & 26.5 & 24.7 \\
\hline TS $(\%)$ & 71.2 & 55.0 & 38.2 & 35.3 & 38.3 & 73.2 & 88.5 & 95.0 \\
\hline $\operatorname{TrS}(\%)$ & $\begin{array}{c}9.4 \\
-\cdots-\end{array}$ & 14.0 & 6.9 & 5.9 & 6.9 & 8.9 & 10.2 & 11.2 \\
\hline \multicolumn{9}{|l|}{ Тоуота AC Macedonia } \\
\hline Phone & 1119 & 93 & 14 & 21 & 41 & 23 & 17 & 24 \\
\hline Leads & 0 & 0 & 0 & 0 & 0 & 0 & 0 & 0 \\
\hline Footfall & 5001 & 417 & 143 & 221 & 392 & 299 & 189 & 263 \\
\hline Leads & 5547 & 462 & 151 & 234 & 405 & 312 & 187 & 279 \\
\hline Total traffic & 6120 & 510 & 157 & 242 & 433 & 322 & 206 & 287 \\
\hline Total leads & 5547 & 462 & 151 & 234 & 405 & 312 & 187 & 279 \\
\hline Test & 1523 & 127 & 53 & 104 & 226 & 169 & 107 & 121 \\
\hline Sales & 570 & 48 & 17 & 47 & 137 & 65 & 33 & 48 \\
\hline \multicolumn{9}{|l|}{ KPI (Gold Standard) } \\
\hline TrL\% - Phone traffic to leads (\%) & 0.0 & 35.0 & 0.0 & 0.0 & 0.0 & 0.0 & 0.0 & 0.0 \\
\hline TrL\% - Footfall traffic to leads (\%) & 110.9 & 75.0 & 105.6 & 105.9 & 103.3 & 104.3 & 98.9 & 106.1 \\
\hline $\mathrm{LT}(\%)$ & 27.5 & 50.0 & 35.1 & 44.4 & 55.6 & 54.2 & 57.2 & 43.4 \\
\hline $\mathrm{TS}(\%)$ & 37.4 & 65.0 & 32.1 & 45.2 & 6.6 & 38.5 & 30.8 & 39.7 \\
\hline $\operatorname{TrS}(\%)$ & 9.3 & 22.0 & 10.8 & 19.4 & 31.6 & 20.2 & 16.0 & 16.7 \\
\hline
\end{tabular}

Table 2

Conversion indicators of 4 different sales persons [1] (\%)

\begin{tabular}{lcccc}
\hline \hline & TrL & LT & TS & TrS \\
\hline Salesman A & 86.0 & 52.0 & 36.0 & 16.0 \\
Salesman B & 99.0 & 38.0 & 32.0 & 12.0 \\
Salesman C & 93.0 & 44.0 & 32.0 & 13.0 \\
Salesman D & 90.0 & 42.0 & 28.0 & 11.0 \\
\hline \hline
\end{tabular}

Figure 3 is a diagram of the conversion indicators for the four retailers from the same retail outlet. By analyzing sales-level comparisons, in order to drive each salesperson to increase sales in terms of equal customer traffic, conversion indicators can be found. They can enable easier and more economical approach to increase sales, rather than the traditional approach of simply increasing customer traffic through increased spend on advertising, promotion and similar marketing tools. Such tools are absolutely necessary, but not in the role of masking sales productivity results. 


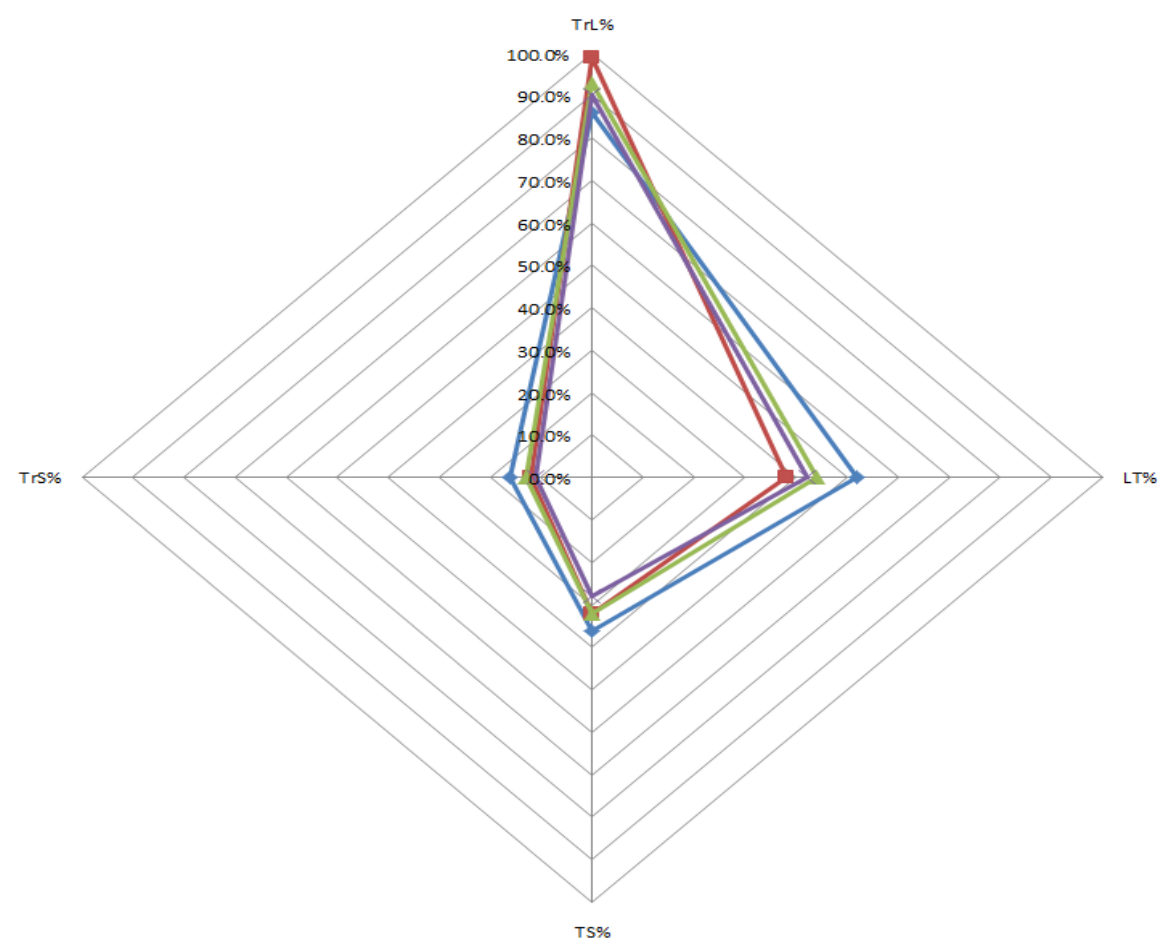

Fig. 3. Diagram of conversion indicators for 4 different salesmans from the same retail outlet [1]

Using the data in Table 2, assuming that within one month each salesman processed a quantitatively equal volume of customer traffic (for every 100 customers per salesman, there are in total 368 types,
161 tests and 52 successful sales), the conversion indicators are calculated at the whole point of sale. The calculated values are [1]:

\begin{tabular}{ccccc}
\hline \hline Indicators: & TrL\% & LT\% & TS\% & TrS\% \\
\hline $\begin{array}{c}\text { Calculation for retail sales point } \\
\text { with 4 salesmans }\end{array}$ & $100 * 368 / 400$ & $=100 * 161 / 368$ & $=100 * 52 / 161$ & $=100 * 52 / 400$ \\
\hline \hline
\end{tabular}

Salesman A achieved 16\% conversion of customer traffic to sales which is above the total sales outlet indicator of $\operatorname{TrS} \%=13 \%$. From the conversion rate data for Greece [1] and the Table 1. Conversion rate for the Athens and Thessaloniki outlets, it is evident that this is a result which is at an average level. By further analysis of all conversion indicators, it can be concluded that salesman A's performance can be improved and is not commensurate with the sales outlet's performance.

Analyzing salesman A, it has a high percentage of success when it comes to convincing its leads to test the product, and does the same testing better than other salesmans, i.e. the average point of sale, because there is a higher percentage of success in conversion to those tests $\mathrm{TS} \%=36 \%$ in sales. Otherwise, salesman A has the lowest indicator of converting customer traffic into leads $\operatorname{TrL} \%=86 \%$, compared to the $\operatorname{TrL} \%=92 \%$ average of the entire sales outlet. His score is far below the most successful at outlet in this category, i.e. salesman B with its score of $\operatorname{TrL} \%=99 \%$. This means that for some realistic reason, salesman A does not achieve a good result in the first conversion. If it were to do better, i.e. the conversion indicator $\mathrm{TrL} \%$ is higher, the potential conversion opportunities from leads to tests would increase, leading to more sales. This does not mean that the LT\% and TS\% indicators need to have the same conversion rate, but it does mean that the end result for the $\mathrm{TrS} \%$ indicator will be higher. In practice, the above shows that it is the result of a quick abandonment of salesman A by 'heavier customers', or so-called 'cherry picking', where customers who are on any grounds a greater 
challenge to salesman A are dismissed because he believes he is losing time on them. The real stereotype of these salesmans is more experienced and older salesman, with many products sold and built on intuitive experience. He respects the theoretical settings of sales, but believes more in his "internal mechanisms". That way of working can make him the best, but never to the best of his abilities.

Salesman $\mathrm{C}$ is in line with the outlet's average performance, absolutely at every level and consequently with the opportunity to improve at each of those levels because in each of them there is another salesman who does it better.

Salesmans B and D are performing well, but each has a weaker feature that prevents them from giving better overall results. The first has the weakest conversion from leads to tests, and the second has the lowest conversion from test to sales. To improve this, additional training, improved product knowledge as well as negotiation training and sales psychology training is required.

This analysis of the conversion shows that even if the total number of customer traffic entries in a single point of sale remains the same, the number of sales can be increased by properly identifying and detecting the weaknesses of individual team members.

The problem of measuring the weaknesses and qualities of individual salesmans is overcome by the use of sales conversion funnel. Stability and consistency of conversion indicators is a powerful tool for validating the value of metered data and a basic prerequisite in the process of correcting and improving conversion indicators.

\section{APPLYING CUSTOMER TRAFFIC CONVERSION TO LOCAL RETAIL CHAIN - CASE STUDY -}

The case study considered to be analyzed as a second is in some way opposite to the previous one, but on the other hand with very clear similarities.

Unlike the automotive industry case study, where there is quantitatively less customer traffic and where most potential buyers can directly identify themselves by name, surname, email, address, etc., which enables a high degree of traceability, as a case of analysis, retail consumer electronics with massive customer traffic and less customer identification will be taken.

In the consumer electronics chain investigated, it will be about applying methods and procedures that are at an early stage and are limited to a part of the retail network. The retail chain that is being analyzed is in the area of consumer electronics. It is a leader in retailing with a $40 \%$ market share in Macedonia, yet it faces not only strong market competition but also a growing consumer culture with its customers. They are becoming more educated, more selective and with greater expectations of equity for their money.

This means that focusing on customer satisfaction and their increased level of loyalty is a priority for positive business and competitive advantage.

\subsection{Defining measurable parameters}

In order to determine the parameters that need to be measured in general, the AIDA model (Figure 4) must be adapted to the work operation, organization and structure in question [1]. In this case, it is necessary to identify and establish a one-way relation between the quoted elements of the AIDA model and the everyday process in the retail consumer chain.

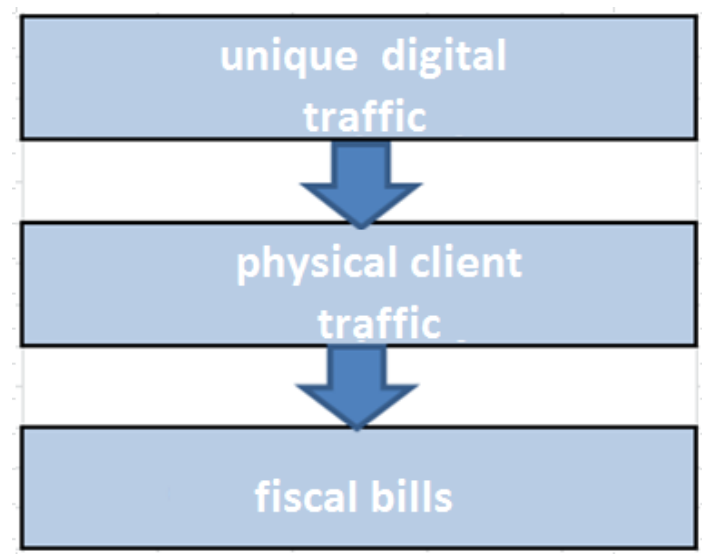

Fig. 4. Adapted sales funnel in consumer electronics retail chain [1]

It is obvious that the element of the AIDA model of action should be linked to the generated fiscal account or actual sales as the final target action by the client. Here it is important to distinguish between the number of products sold to customers and the number of customers to whom products are sold.

After identifying the first two elements of the AIDA model, it is also necessary to identify the remaining two elements: awareness and interest. In a mass retail chain without the ability to fully identify each customer, these two elements are merged into one new element, the so-called "interest". 
The element of interest includes any customer who is aware of a product or service and has done something that clearly highlights his or her interest. In a situation where the interaction as a consequence of consciousness is interpreted as a manifestation of interest, it is necessary to identify how a manifest element of interest will be measured by different marketing campaigns.

The channels for executing the marketing campaigns to be measured are: digital marketing, television, radio, billboards.

It is clear that digital marketing is a common denominator of all marketing campaigns and it is a constant presence in all campaigns, has easy measurability and a high degree of interaction overflow from other channels.

This element of interest will include all the unique customers who interacted through digital channels, social media and websites, with one name: unique digital traffic.

Once all the necessary elements have been identified, the AIDA model sales conversion funnel, adapted for the business operation of the consumer electronics retail chain, is shown in Figure 4.

The adapted conversion sales funnel not only provides a direct measure of the success of the sales process, indirectly measures the customer satisfaction and trend of Upsale and Cross-sale, but also provides a huge opportunity to measure the success of marketing and commercial campaigns.

When digital marketing creates high unique digital traffic to the target compatible customer group, and that interest is not translated into customer physical traffic at the outlets, this means that a proper and successful marketing campaign was created, but it was not commercially attractive enough to bring customers to the point of sale. For example, the products were expensive, there was not a wide enough range, the competition had attractive added value to similar or identical products and so on.

In a situation where there is low digital traffic despite engaging resources and marketing campaigns, then either the target group is incompatible with the action or the marketing creative and communicative message itself is not attractive enough.

If, despite the low digital traffic, there is a high turnover of retail sales, it means that marketing communication was poor, but the commercial offer was attractive to the extent that it created a high level of sales conversion.

\subsection{Introducing a system of measurement and analysis}

Once the adapted sales conversion funnel according to the AIDA model is already defined, different conversion indicators need to be defined.

For the given adapted funnel they are as follows:

$\mathrm{DF} \%=100 *$ footfall traffic / digital unique traffic

$\mathrm{DS} \%=100 *$ number of fiscal bills / digital unique traffic

FS $\%=100 *$ number of fiscal bills $/$ footfall traffic

The first indicator DF\% represents the degree of conversion from digital to physical traffic. The higher the value of the indicator, the more successful the marketing action is. It is very important to emphasize that such indicators should be measured within the duration of the action or actions, and that the initial conversion is not immediate but within one to several days.

The second indicator DS\% represents the degree of commercial success of the actions themselves, i.e. the percentage of successful sales of a given number of digital traffic.

The third indicator FS\% is by far the most important for sales teams in the outlets themselves because it measures how successful sales are made by a given number of physical inputs per unit of time at the outlet.

For the point of sale management, the FS\% is the most important indicator because it closely reflects the success, salesman training and degree of customer satisfaction and service.

Most important for the marketing department is the DF\% conversion indicator that reflects the efficiency and effectiveness of their primary purpose, i.e. to generate interest and bring potential customers to the point of sale.

The conversion index DS\% is the most important for the product management department. Namely, this department selects which products, when, how long, and under what conditions and prices will be the subject of a campaign for which the marketing department should choose creatively and choose channels and frequency of communication.

In order to better illustrate the three conversion indicators, an example is shown of 3 different campaigns at 3 outlets in the same consumer electronics retail chain, in terms of different commercial offers 
in each campaign. Conversion indicators are shown in Table 3. Digital customer traffic values are provided by Google Analytics, physical traffic values are provided by in-store gauges, and the number of sales is actually the number of fiscal accounts generated.

\section{T a b l e 3}

Conversion indicators of adapted sales funnel into 3 sales campaigns at 3 sales points (\%) [1]

\begin{tabular}{llll}
\hline \hline Campaign & DF & DS & FS \\
\hline 1. Outlet A & 5.0 & 2,5 & 50.0 \\
1. Outlet B & 5.0 & 2,8 & 56.0 \\
1. Outlet C & 5.0 & 2,4 & 48.0 \\
\hline 2. Outlet A & 8.0 & 4,2 & 52.0 \\
2. Outlet B & 8.0 & 4,7 & 59.0 \\
2. Outlet C & 8.0 & 3,9 & 49.0 \\
\hline 3. Outlet A & 3.0 & 1,3 & 43.0 \\
3. Outlet B & 3.0 & 1,5 & 51.0 \\
3. Outlet C & 3.0 & 1,2 & 41.0 \\
\hline \hline
\end{tabular}

It can be seen from Table 3 that the conversion factor DF\% has the same value for each campaign in each point of sale. Namely, the provision of digital customer traffic data is at the city level and it is impossible to divide sales outlets. Therefore, average customer traffic is taken from all over the city for each outlet.

The conversion indicator $\mathrm{DS} \%$ can also be calculated as a product of the other two indicators, i.e. the following equation:

$$
\mathrm{DS} \%=\mathrm{DF} \% * \mathrm{FS} \%
$$

When already within a city, the conversion factor DF\% has the same value for all points of sale, that is, it is constant, and clearly from the above equation the indicator DS\% is directly proportional to the indicator FS\%, which means that the complete comparative difference between point of sale within a city is made by the $\mathrm{FS} \%$ indicator.

When analyzing the three campaigns, it is evident that within each campaign outlet $\mathrm{B}$ has the best performance. Namely, the DS\% is the highest value due to the highest conversion of physical customer traffic into successful sales, which is constantly above $50 \%$. This means that on average for every two customer entries, there is at least one sale. The consistency in performance is also present in the other two outlets, $\mathrm{A}$ being better than $\mathrm{C}$ which is consistently the worst. This consistency in the rankings of conversion indicators stems from the fact that no matter which campaign is being run and how successful the potential buyers are in the point of sale, better salesman training in outlet B creates higher success, higher percentages and higher customer satisfaction.

The conclusion of this analysis is that higher levels of training and customer satisfaction enable higher conversion of customer traffic into sales, no matter how successful the campaign is or what the commercial offer is.

In conclusion, it can be concluded that within each sales point, campaign number 2 is by far the most successful. It has, without exception, produced the best results on the FS\% indicator. The common denominator of all sales points in campaign number 2 is that the conversion factor $\mathrm{DF} \%$ is the highest value. This means that much of the unique digital traffic is being channeled into physical traffic. The fact that the highest value of the DF\% conversion indicator is supported and the highest value of the DS\% and FS\% indicates that not only was there a successful marketing campaign but also a successful commercial bid. In addition, it is noticeable that the campaigns with the highest indicator DF\% have the highest indicator FS\%, and vice versa, although these two conversion rates are not directly correlated.

It concludes that within equal sales training and customer satisfaction, the best results are achieved when a successful marketing campaign is backed by a good commercial offer.

The biggest disadvantage of such an analysis is that the limitation of providing unique digital traffic data for each point of sale separately creates serious statistical errors in the conversion of digital to physical traffic. Therefore, despite monitoring all the statistical parameters for digital traffic, the greatest attention is needed to be paid to the conversion from physical traffic to actual sales, i.e. the FS\% conversion indicator.

On average, at the retail level, the value of the FS\% is around $50 \%$, which in terms of purchasing power and consumer culture as it is in Macedonia is excellent. It is the result of consistency in sales training and application of customer satisfaction creation procedures. 


\section{CONCLUSION}

An analysis of two companies from different industries, with different cultures and sizes, showed that the impact of the success of customer traffic processing on customer satisfaction and profitability of the company is enormous. In both cases under consideration, the local retail chain and Toyota's international retail organization, the analysis model is based on conversions of an adapted sales funnel derived from the AIDA model.

The analyzed sales data from Toyota is generated from the IA (Inchcape Advantage) portal which provides an additional opportunity to compare not only by analyzing its own seasonality and history, but also by related companies. It has been shown that there are major differences globally in customer traffic conversions in different markets, primarily due to differences in cultural habits, purchasing power and tradition. On the other hand, the analysis of conversion sales funnel indicators in different markets confirmed the thesis that markets with similar cultural habits, purchasing power and tradition have similar conversion indicators, not only at the whole market level but also at the city level.

Analyzing several markets over a period of 3 years, it has been shown that although NPS tools and Mystery Shoppers (MS) are closely linked - MS does not always correlate with the same trend. The reason is that the Mystery Shoppers tool will more specifically determine the degree of practical use of the basic procedures in the sales process, as opposed to the value of service that shapes customer satisfaction measured through the NPS tool. In essence, these results highlight and confirm the need for systematic and controlled use of all the methods and procedures defined in the process of implementing the NPS tool as the ultimate tool for controlling, monitoring and enhancing customer satisfaction. However, the NPS tool is not without weaknesses. The biggest weakness is that it is divided into only three groups: promoter, detractor and passive, which allows for greater diversification that will remain hidden in the results obtained.

Adapting the sales funnel to a local retail chain has shown the impact of digital marketing as a common denominator of all marketing actions that enables easy measurability and a high degree of interaction overflow from other channels. Digital marketing is represented by the first element in the adapted funnel, unique digital traffic. When analyzing sales at 3 outlets in 3 different campaigns, it was concluded that higher levels of training and customer satisfaction enable higher conversion of customer traffic into sales, no matter how successful the campaign is or what the commercial offer is. It further concludes that with equal sales training and customer satisfaction, the best results are achieved when a successful marketing campaign is backed by a good commercial offer.

The main purpose of the examples presented for the successful use of tools and methodologies is to focus on clients as a major competitive advantage. It should be performed by all instances of the company's sales and management team. At the same time, every investment should be accompanied by the implementation of transparent motivation and reward for the hard work of the employees.

\section{REFERENCES}

[1] Boceski, G.: Quantitative Analysis Methods of Sales and Customer Satisfaction, Master thesis, Faculty of Mechanical Engineering, Skopje, January 2020 (in Macedonian).

[2] Lewis, E. St. Elmo: Financial Advertising (The History of Advertising), Garland Publ., New York, 1985.

[3] Murley, P.: Handbook of Customer Service, Gower Publishing, Ltd., 1997.

[4] Kessler, S.: Measuring and Managing Customer Satisfaction: Going for the Gold, ASQC Quality Press, 1996.

[5] Biswas, S.: Relationship Marketing: Concepts, Theories and Case, PHI Learning Pvt. Ltd., 2014.

[6] Hoos, A.: The Sales Funnel Bible: How to Generate More Leads, Turn More of Them into Customers, and Do It All Faster, Easier, and for More Profit, Create Space Independent Publishing Platform, 2014.

[7] Graham, D.: Advantage Way of Selling, Inchcape Strategic Center, 2009.

[8] Pamln, Ca.: The Essential Guide to Mystery Shopping, Happy About, California, 2009.

[9] Owen, R., Brooks, L. L.: Answering the Ultimate Question: How Net Promoter Can Transform Your Business, John Wiley \& Sons, 2009.

[10] TMC: Toyota Code of Conduct, Toyota Motor Europe, 2006.

[11] Liker, J. K.: The Toyota Way - 14 Management Principles from the World's Greatest Manufacturer, McGraw-Hill Education, 2004.

[12] Reicheld, F.: The Ultimate Question 2.0, Harvard Business Review Press, 2011.

[13] https://www.thedesiredpath.com/amp/introducing-thereal-customer-funnel, (Accessed на 15.02.2019).

[14] https://www.medallia.com/net-promoter-score/ (Accessed on 28.11.2019). 